\title{
Seed System Dynamics and Crop Diversity of Chinbaung in Myanmar
}

\author{
Mami Nagashima, Yoshiaki Nishikawa, Mya Shew, Obm Mar \\ Saw, Min San Tein, Makoto Kawase, Kazuo Watanabe, \\ and Kenji Irie
}

\begin{abstract}
In this field survey of seed system dynamics in Myanmar, the authors note that the country's dominant system of traditional agriculture faces pressure from the introduction of 'improved' varieties and shifts in policy. However, farmers-from small and subsistence growers to large-scale rice producers-continue to raise indigenous species. One is chinbaung, the collective term for several varieties in the genus Hibiscus. The authors traced differences in chinbaung cultivation and use among
\end{abstract}

\footnotetext{
M. Nagashima $\cdot$ K. Irie

Tokyo University of Agriculture, Setagaya, Tokyo, Japan

Y. Nishikawa $(\bowtie)$

Ryukoku University, Kyoto, Japan

e-mail: nishikawa@econ.ryukoku.ac.jp

Mya Shew

Yezin Agricultural University, Naypyidaw, Myanmar

Ohm Mar Saw · Min San Tein

Ministry of Agriculture, Livestock and Irrigation, Naypyidaw, Myanmar

(C) The Author(s) 2022

Y. Nishikawa and M. Pimbert (eds.), Seeds for Diversity and Inclusion, https://doi.org/10.1007/978-3-030-89405-4_6
} 
places, and examined production systems in three villages in central arid zone, each sited in a geographically distinct locale. They found that a local festival popular with seed sellers has become a prime conduit for disseminating diverse genetic resources. Poe Yon, a guild of agricultural brokerage firms with hubs in cities across the country, meanwhile involves firms and farmers in a unique relationship that ensures broader distribution. Ultimately, the autonomy of farmers has enabled agrobiodiversity to thrive in Myanmar-a success, the authors note, that agricultural policymakers should heed.

Keywords Chinbaung - Festival · Hibiscus - Myanmar · Poe Yon · Vegetable

\subsection{INTRODUCTION}

Myanmar's crop diversity is rich, thanks to its subtropical location, varied climate and adherence to traditional agricultural practices. The country's policy of isolation from the international community under the junta regime (1962 to 2011, resuming in 2021) has meant that agriculture has been slow to modernise.

Recent development policies emphasising democratisation and economic growth have, however, sparked concern about the loss of genetic diversity (Thein et al., 2017; Tun \& Than, 1996). Improved varieties have been actively introduced (Ministry of Agriculture and Irrigation, 2015) through international collaboration, and have also been imported commercially from countries including Thailand, China and Taiwan. It is increasingly common to find farmers growing just a few indigenous crop varieties in their backyards, not only because of the government's policy to promote improved varieties but also because many farmers wish to boost their income.

\footnotetext{
M. Kawase

Tokyo University of Agriculture, Atsugi, Japan

K. Watanabe

University of Tsukuba, Tsukuba, Japan
} 
In light of this situation, this chapter focuses on the crops collectively called chinbaung in Myanmar. This Burmese term refers to several species in the genus Hibiscus which have long been grown across the country. We describe chinbaung's diversity in terms of biology, cultivation and culinary use, and analyse the processes through which that diversity is preserved, giving particular emphasis to different modes of seed procurement and distribution.

\subsection{Chinbaung Diversity: Cultivation and Use}

Chinbaung is cultivated on small and subsistence farms, and the species are also grown as a secondary crop by industrial farmers in Myanmar. For small farmers, the crop is a critical source of income as it requires less investment in fertilisers, pesticides and irrigation facilities. It is also easy to grow, and produces a stable yield for long periods, even under extremely dry conditions. By contrast, for large-scale rice farmers, chinbaung is a secondary source of income during the off-season. For agriculture in Myanmar generally, the crop underpins income stability, as other major crops are often at risk from flooding and drought.

The authors and colleagues collected 342 samples of chinbaung from around Yangon, Myanmar's largest city, as well as the central arid zone, the northeastern highlands and the southern delta from 2014 to 2018 (Domon et al., 2015; Nagashima, Yoshida et al., 2019). The findings for the five Hibiscus species are shown in Table 6.1.

H. sabdariffa is a Hibiscus species most commonly cultivated in Myanmar: it was found in all the administrative divisions surveyed. The second most frequently cultivated, $H$. cannabinus, was found in large numbers in the central arid zone. $H$. radiatus and $H$. acetosella were found more often in Chin State (a western mountainous state) than elsewhere. We surmised that the species grown in each region have been selected because of conditions such as temperature, precipitation and isolation due to the mountainous topology, which may have affected the establishment of different types (Mohamed et al., 2015; Sharma et al., 2016).

It was found that even when growing the same crop species, farmers sowed a mixture with different morphological characteristics, such as leaf size, stem height and rooting pattern. That implies that at least some of the plants can survive and flourish under varying, sometimes unexpected environmental conditions because they may have diverse adaptive 
Table 6.1 Breakdown of collected samples of five Hibiscus species by district and state

\begin{tabular}{|c|c|c|c|c|c|c|}
\hline $\begin{array}{l}\text { Administrative } \\
\text { district/division }\end{array}$ & $\begin{array}{c}\text { H. } \\
\text { sabdariffa }\end{array}$ & $\begin{array}{c}\mathrm{H} . \\
\text { cannabinus }\end{array}$ & $\begin{array}{l}\mathrm{H} . \\
\text { radiatus }\end{array}$ & $\begin{array}{c}\mathrm{H} . \\
\text { acetosella }\end{array}$ & $\begin{array}{c}\text { H. } \\
\text { surattensis }\end{array}$ & Total \\
\hline Kachin state & 16 & 1 & 0 & 0 & 0 & 17 \\
\hline Sagaing region & 37 & 8 & 2 & 1 & 1 & 49 \\
\hline Chin state & 11 & 2 & 11 & 5 & 0 & 29 \\
\hline Shan state & 39 & 3 & 2 & 2 & 0 & 46 \\
\hline Mandalay region & 36 & 25 & 6 & 0 & 0 & 67 \\
\hline Magwe region & 38 & 11 & 3 & 0 & 0 & 52 \\
\hline Kayah state & 0 & 0 & 0 & 0 & 0 & 0 \\
\hline Kayin state & 2 & 0 & 0 & 0 & 0 & 2 \\
\hline Bago region & 15 & 6 & 3 & 0 & 1 & 25 \\
\hline Yangon region & 14 & 2 & 0 & 0 & 0 & 16 \\
\hline Mon state & 17 & 0 & 0 & 0 & 0 & 17 \\
\hline $\begin{array}{l}\text { Ayeyarwardy } \\
\text { region }\end{array}$ & 11 & 0 & 3 & 0 & 0 & 14 \\
\hline $\begin{array}{l}\text { Tanintharyi } \\
\text { region }\end{array}$ & 8 & 0 & 0 & 0 & 0 & 8 \\
\hline Total & 244 & 58 & 30 & 8 & 2 & 342 \\
\hline
\end{tabular}

traits, such as photoperiodic responsiveness, drought tolerance and/or resistance to cold or moisture, along with their range of morphological traits. The farmers told the authors that the practice reduces the risk of losing yields because of sudden deterioration in the weather.

We found that different chinbaung species were selected and used according to a range of purposes and taste preferences. H. sabdariffa is utilised as a food and fibre, and also has roles in medicine, dye, oil, pulp and fuel. Its versatility has made it a popular crop in resource-poor villages, and in small or garden farming. We discovered that $H$. sabdariffa exhibits five different morphological variations, while $H$. cannabinus, $H$. radiatus and $H$. acetosella are bimorphic (Nagashima et al., 2019). Furthermore, many minor differences have been found within each type.

\subsection{How FARMERS UsE Chinbaung Seeds in Cultivation}

Chinbaung is a frequent component of inter-cropping schemes, cultivated with rice in flood-prone areas in large plots up to 4 or 5 hectares (ha) in 
area, used in mixed cropping with other vegetables and pulses, or planted as a vegetable in domestic gardens. In the case of inter-cropping with rice, chinbaung serves as a subsidiary source of income. Chinbaung is also planted around oil crops such as sesame and sunflower to mitigate the risk of failure from drought, because the leaves as well as seeds can be harvested, which is not possible for the other oil crops.

$H$. sabdariffa blooms during the dry season around November, when there are under 13 hours of daylight, allowing the seeds to be harvested from December onwards. Many farmers don't purchase seeds, but collect them from their own fields to use for cultivation the following year, which reduces costs. This practice also maintains the selected crop traits, and can boost income via seed sales.

With such on-farm seed production, however, chinbaung must stay in the fields longer. The H. sabdariffa crop remains in the ground for more than a month after the leaves are harvested. Seed production is therefore limited to areas where farmers have plots large enough to accommodate that, on terrain less likely to be affected by events such as flooding. Sufficient income from the previous year's seed production is also key to the production of high-quality seeds, while continuous mutual agreement between seed growers and seed users will ensure the ongoing provision of such seeds. It is likely that the contractual production system contributes to the improvement of the quality of seeds and also the selection of varieties adapted to each area.

Similar contractual production systems are sometimes adopted by rice farming communities far from areas where chinbaung seed is produced. Lands around the township of Shwebo District in Sagaing Region, for instance, are sown with high-quality rice, with chinbaung intercropped as a source of additional income. Local farmers order the chinbaung seeds before sowing rice (around October to November) every year, purchasing them from seed suppliers, or seed producing farmers in the nearby village of Yao Te, who are paid when seed for the following year is ordered. This type of contract establishes a network in which specialised farmers produce high-quality chinbaung seed.

In some mountainous areas, by contrast, seeds are not collected after the vegetable harvest. For instance, in Taunggyi in Shan State, most farmers grow chinbaung for their own consumption, and allow seeds to fall and spontaneously germinate so they grow again the following year. Commercial suppliers in this area often sell seeds in small quantities, since the crops are largely confined to domestic gardens. 
The circulation of H. sabdariffa seeds in Sagaing Region has revealed that seed farmers grow a mixture of varieties with different flower colours and morphological traits, as well as other chinbaung species. The farmers harvest the seeds without sorting or labelling them before shipping them to local seed suppliers; hence, any genetic mixture in seeds in this market can be human-induced.

In addition, some farmers around the township of Monywa District in Sagaing Region use different plots for the production of vegetables and chinbaung seed. These farmers produce seeds by sowing any remaining seeds in isolated plots after the vegetable growing season. The goal is not to select and maintain superior traits, but to secure income through the efficient use of vegetable plots.

\subsection{Cultivation and Seed Procurement Methods in Relation to Flooding}

Three adjacent villages (Ye Le Kyun, Yin Taw and Ywa Thit) in the central arid zone (Sagaing and Mandalay regions) were studied to explore residents' roles, relationships and attitudes vis-à-vis different vegetable and seed production systems. Chinbaung is widely cultivated across the regions. We also discovered related events such as the Shwe Kyun Pin Nat Festival (see Sect. 6.5), and bodies such as Poe Yon, a unique brokerage organisation that can influence these factors (see Sect. 6.6).

A comparison of the three villages revealed that geographical factorstheir locations in relation to the river, each other and nearby citiesaffected the forms of agriculture and methods of seed procurement used in each (see Fig. 6.1).

Ye Le Kyun (see Fig. 6.2) is sited on a towhead, or low-lying alluvial island, surrounded by river water during the rainy season. Farmers here produce a variety of seeds on a small scale and earn a profit by selling small quantities at high prices at Shwe Kyun Pin Nat Festival, held near the village; there are no large towns or seed suppliers nearby.

The fields of Yin Taw are not sowable in the rainy season. However, the village is close to two large cities, Sagaing and Mandalay, both of which have vegetable markets. Many farmers in Yin Taw focus on vegetable production, and have abandoned seed production altogether. They maximise the use of the land right up to the time when their fields begin to flood, and supply vegetables to the cities. 


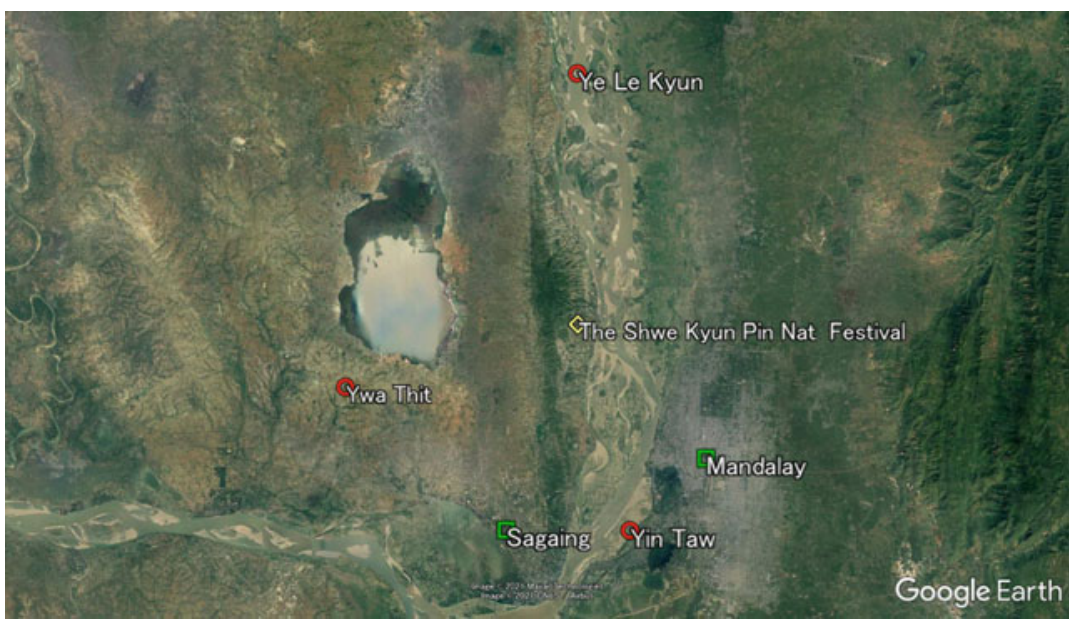

Fig. 6.1 Location of the three villages and Shwe Kyun Pin Nat Festival

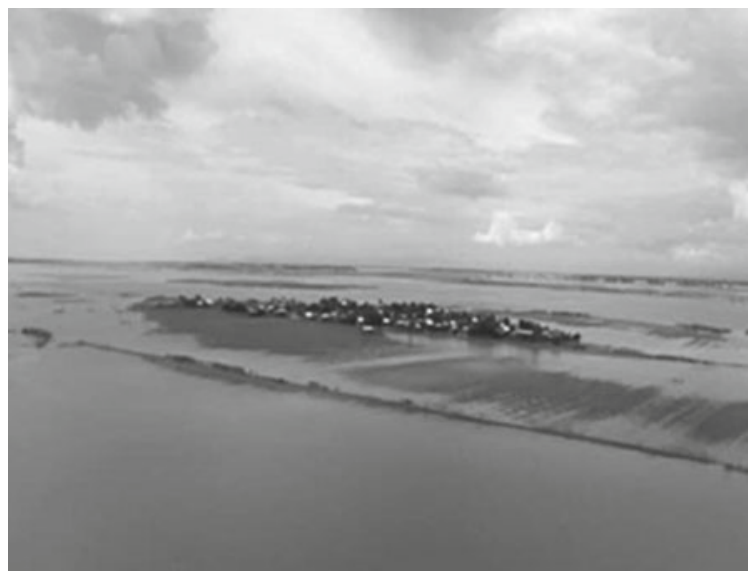

Fig. 6.2 Low-lying Ye Le Kyun during the rainy season

Ywa Thit uses its flood-free location to its advantage, and engages in both dairy farming and seed production. Seeds are sold to neighbouring villages, seed suppliers and Poe Yon (see Sect. 6.6). The villagers also 
engage in the contractual production of high-quality seeds for villages that have difficulty in seed production because of the flood-swollen river.

Various forms of seed production at different scales and of cultivation methods were observed, contributing to the conservation of genetic diversity of chinbaung within and outside the area (Table 6.2).

\subsection{Relationship Between Seed Distribution and the Shwe Kyun Pin Nat Festival}

The Shwe Kyun Pin Nat Festival, held from 12 to 15 August (around the time of the full moon), is one of three major festivals held in Upper Myanmar. It is a grand festival during which local people honour spirits and pray for family health, a stable income and a good harvest (see Fig. 6.3).

During the festival, the shrine of the Shwe Kyun Pin Sister and Brother is surrounded by stalls selling local products such as bamboo crafts and unglazed water bottles, as well as local culinary specialities specific to the festival. Women from Ye Le Kyun and neighbouring villages sell seeds of various crops (see Fig. 6.4).

Farmers in flood-prone areas, where it is difficult to harvest or store seeds, purchase seeds even at relatively high prices at the festival. Each of the seed dealers who gather for the festivities sells on average seeds of 21 crop species, including Hibiscus sabdariffa (roselle) and $H$. cannabinus (kenaf), Lablab purpureus (hyacinth bean), Vigna unguiculata (cowpea, also known as black-eye pea), Benincasa hispida (wax gourd), Ipomoea aquatica (water spinach), Luffa cylindrica (sponge gourd), Cucurbita maxima (pumpkin) and Coriandrum sativum (coriander). Of these, $H$. sabdariffa and $H$. cannabinus are sold in particularly large quantities. According to tradition, seeds purchased at the festival are believed to promise good luck, and to yield a good harvest.

At the festival, some of the seeds produced in very small quantities by small-scale farmers are collected and mixed, and sold not only to locals, but also to farmers visiting from beyond the region. These seeds may include morphologically different phenotypes that we have seen in the village fields surveyed. In this way, diverse genetic resources are widely spread and shared throughout the festival. At the same time, farmers from Ye Le Kyun, whose conditions and location constrain seed production, ensure the dissemination of diverse strains of chinbaung via festival traditions. 


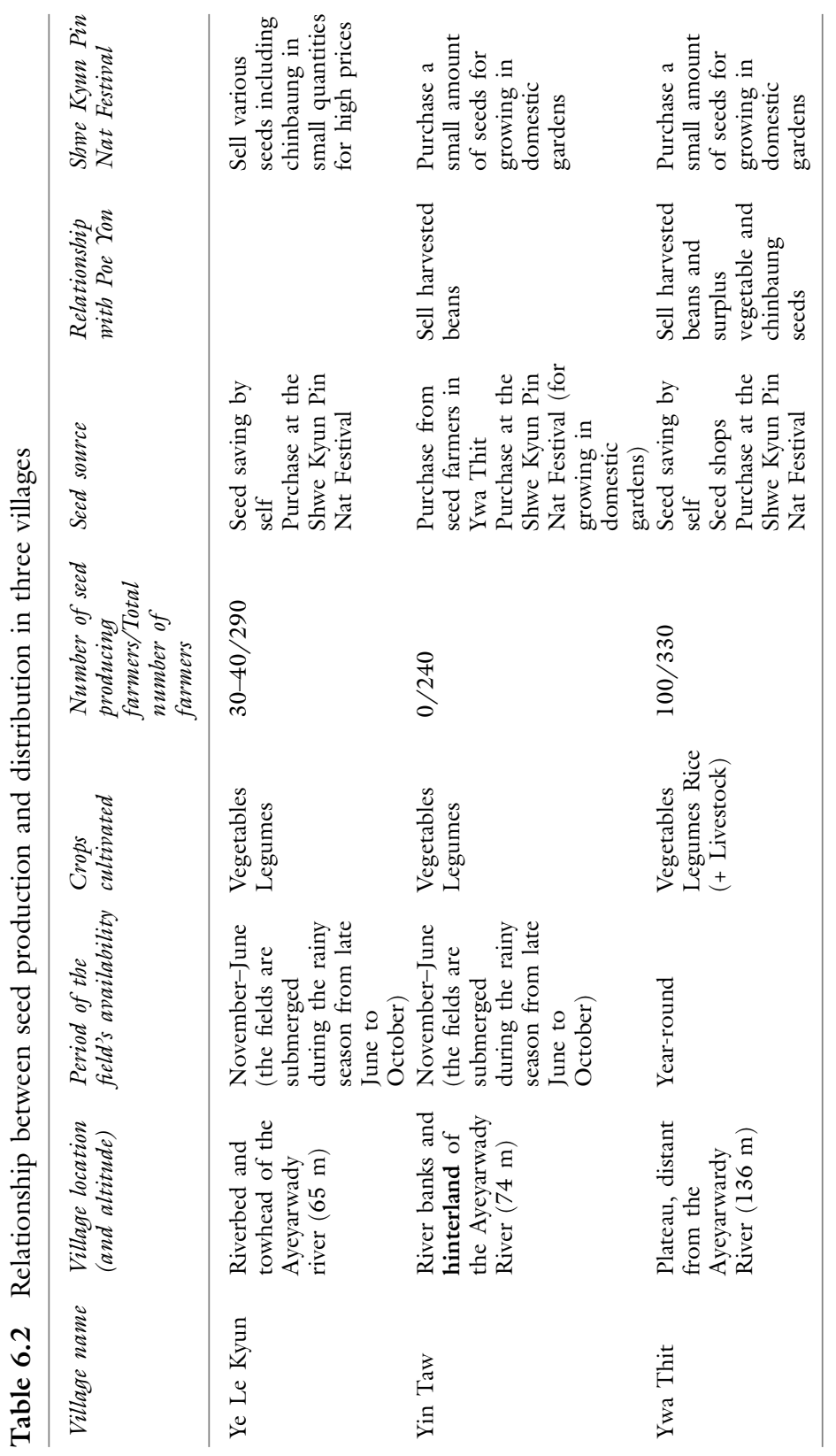




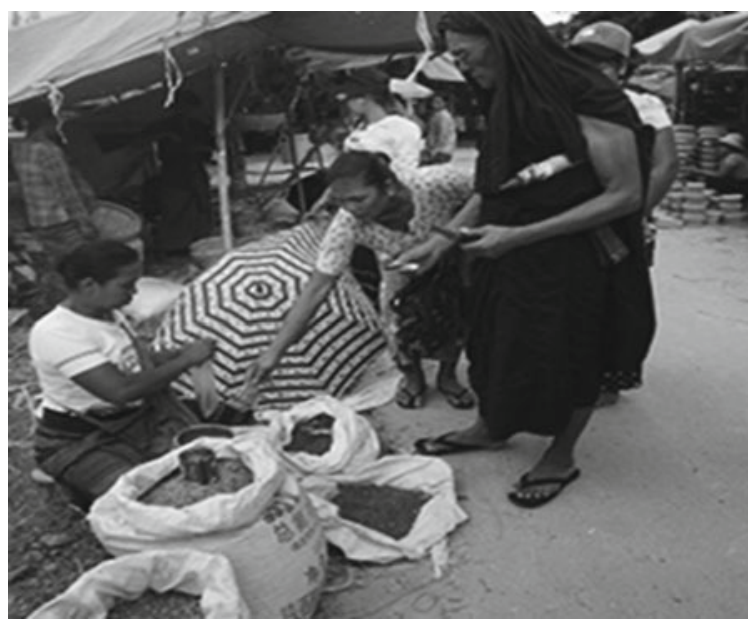

Fig. 6.3 A monk buying seeds at the Shwe Kyun Pin Nat Festival

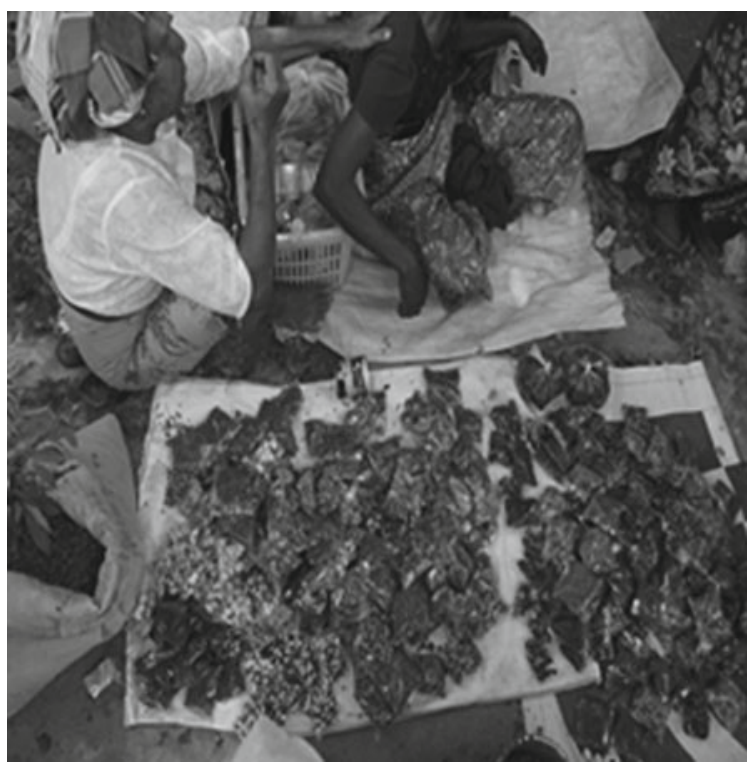

Fig. 6.4 A seed seller at the Shwe Kyun Pin Nat Festival 


\subsection{The Role of Poe Yon, a Distinctive Stakeholder}

Poe Yon is a kind of guild for the private agricultural brokerage firms seen in large and small cities in Myanmar. Each Poe Yon firm deals with crops, such as oil crops, rice, fresh vegetables, fruits or flowers. All of the firms are privately owned and operated, mainly by family members, and are connected with other Poe Yon firms in the same city and adjacent areas, forming a cooperative association for the exchange of information and regulation of commodity prices. They are also connected with their counterparts in other cities through broad information networks and distribution channels, and frequently use them to exchange goods directly or through bigger merchants, mainly from China.

In Ye Le Kyun, there are also farmers who sell chinbaung seeds alongside harvested legumes to Poe Yon firms run by relatives in Sagaing City. One Poe Yon owner from Ye Le Kyun reported that he sells most of the collected chinbaung seeds to dealers in Sagaing and Mandalay, and the rest to oil factories. We found that chinbaung was, unlike other kinds of vegetables, always much in demand by farmers and seed dealers both as seeds for vegetable production and as oilseed. This indicates the distinctive position occupied by chinbaung in Myanmar. Seeds from largescale and small-scale farmers are also likely to be distributed via the Poe Yon network to various parts of Myanmar, thereby contributing to the maintenance of chinbaung genetic diversity as a whole.

The Shwe Kyun Pin Nat Festival and the unique relationship between Poe Yon firms and farmers play a critical role in the distribution of chinbaung seeds, and are very different from the distribution channels where major seed companies mediate with stakeholders, as is the case with improved varieties of vegetables (Fig. 6.5). 


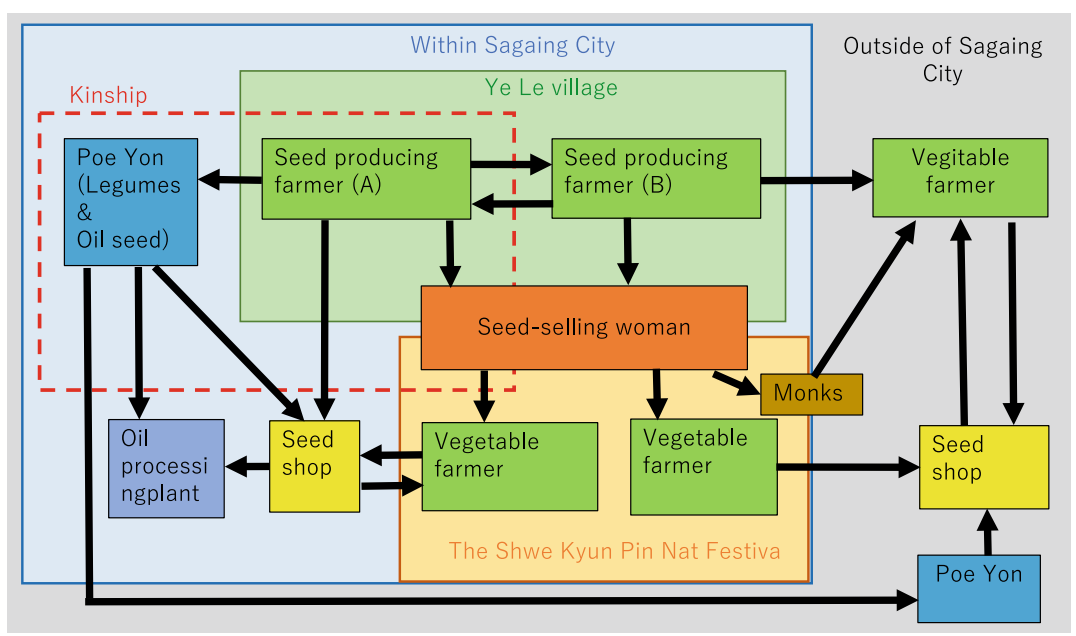

Fig. 6.5 Seed distribution channels in Sagaing City and outside of Sagaing City

\subsection{Conclusion}

Farmers in Myanmar use chinbaung in diverse ways. Many produce chinbaung seeds on-farm for the next cropping season. The main aim, aside from reducing costs, is to grow varieties with superior traits selected by the farmers themselves. However, large-scale rice farmers in the Sagaing and Mandalay Regions purchase seeds for more effective use of their plots via crop rotation, alternating chinbaung cultivation for vegetables with paddy rice production.

Our field survey revealed that small-scale farmers producing vegetables continue to grow diverse species and varieties of chinbaung that are developed and maintained not only according to constraints of the local environment, but also to the demands of livelihoods, through factors such as usefulness for subsistence, taste and versatility. Many traditional varieties are stored and managed in farmers' homes, so farmers who need seeds because of loss from flooding or drought, for instance, can obtain seeds similar to those of their neighbours and home villages. At the same time, the introduction of new varieties or genetic characteristics may lead to the diversification of local varieties.

From interviews with local farmers and members of Poe Yon, we noted that farmers' networks are intimate and cooperative, based on familial or 
territorial ties. In one Poe Yon firm we studied, the owner's wife was from Ye Le Kyun, thus her seed transactions in the village mainly took place with farmers she was related to. Each Poe Yon firm deals with large quantities of a limited number of items - a response to demand from neighbours and distant consumers, and based on a solid network with other Poe Yon firms across different cities. In the Mandalay Region, the Poe Yon firms have formed an association that sets crop prices. A similar association emerging in Yangon and other large cities in Myanmar coordinates its own seed-trading activities and even those with neighbouring China.

This is a good example of how a broad and continuous supply of diverse traditional seeds can be realised through farmers' own decisions, enacted in their fields and through their seed networks. Although farmers have apparently developed their seed acquisition and provision practices spontaneously, and although these practices appeared resilient during our survey, these practices cannot be seen as secure, given the advance of industrialised, commercialised farming in Myanmar. Yet seed diversity is an important component of biocultural heritage as well as sustainable agriculture. We recommend that farmers' practices be integrated into agricultural policy. Such a move contributes to the conservation of crop diversity in relatively small areas, and the sustainability of the human-made distribution system that facilitates crop diversity in larger ones.

Acknowledgements The research has been funded partially by JSPS KAKENHI 17H01682:17H04627.

\section{REFERENCES}

Domon, E., Thein, M. S., Takei, E., Osada, T., \& Kawase, M. (2015). A field study collecting cultivated crops and useful plants in Sagaing region of Myanmar in 2014. Annual Report on Exploration and Introduction of Plant Genetic Resources, 31, 343-365.

Ministry of Agriculture and Irrigation. (2015). Myanmar rice sector development strategy: Building the foundation of a modern, industrialized nation through inclusive agricultural and rural development. Retrieved July 21, 2021, from http://books.irri.org/MRSDS_content.pdf

Mohamed, B. B., Muhammad, B. S., Hassan, S., Rashid, B., Beenish, A., \& Husnain, T. (2015). Tolerance of Roselle (Hibiscus sabdariffa L.): Genotypes 
to drought stress at vegetative stage. Advancements in Life Sciences, 2(2), $74-82$.

Nagashima, M., Irie, K., Yoshida, S., Kikuno, H., Mar Saw, O., Soe, T. T., \& Watanabe, K. (2019). Evaluation of diversity of plant genetic resources grown in Myanmar home garden: Distribution and utilization of Hibiscus genus plant "chinbao." Journal of the International Society for Southeast Asian Agricultural Sciences, 25(1), 104-111.

Nagashima, M., Yoshida, S., Kikuno, H., Wakui, K., Nishikawa, Y., Mar Saw, O., Moe, S., \& Irie, K. (2019). Field survey and collection of "chinbao", Hibiscus spp. in Chin State of Myanmar (20th of December 2017-1st of January 2018). Anmual Report on Exploration and Introduction of Plant Genetic Resources, 34, 137-146. https://doi.org/10.24514/00001138

Sharma, H. K., Sarkar, M., Choudhary, S. B., Kumar, A. A., Maruthi, R. T., Mitra, J., \& Karmakar, P. G. (2016). Diversity analysis based on agromorphological traits and microsatellite based markers in global germplasm collections of roselle (Hibiscus sabdariffa L.). Industrial Crops and Products, 89, 303-315. https://doi.org/10.1016/j.indcrop.2016.05.027

Thein, M. S., Kawase, M., Domon, E., \& Watanabe, K. (2017). A field study to explore plant genetic resources in the Sagaing Region of Myanmar in 2015. Annual Report on Exploration and Introduction of Plant Genetic Resources, 33, 239-263. https://doi.org/10.24514/00001103

Tun, T. \& Than, M. (1996). Myanmar: Country report to the FAO international technical conference on plant genetic resources. FAO. Retrieved July 21, 2021, from http://www.fao.org/fileadmin/templates/agphome/docume nts/PGR/SoWl/asia/MYANMAR.pdf 
Open Access This chapter is licensed under the terms of the Creative Commons Attribution 4.0 International License (http://creativecommons.org/licenses/ by $/ 4.0 /$ ), which permits use, sharing, adaptation, distribution and reproduction in any medium or format, as long as you give appropriate credit to the original author(s) and the source, provide a link to the Creative Commons license and indicate if changes were made.

The images or other third party material in this chapter are included in the chapter's Creative Commons license, unless indicated otherwise in a credit line to the material. If material is not included in the chapter's Creative Commons license and your intended use is not permitted by statutory regulation or exceeds the permitted use, you will need to obtain permission directly from the copyright holder.

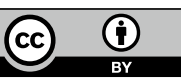

